\title{
Establishment and Evaluation of a Novel Method Based on Loop-Mediated Isothermal Amplification for the Rapid Diagnosis of Thalassemia Genes [Corrigendum]
}

\author{
Wang W, Lin M, Li H, et al. Risk Manag Healthc Policy. \\ 2020;13:303-311
}

On page 309, Sensitivity and Specificity of LAMP Assays in Clinical Assay heading, last sentence "These results showed that the sensitivity and specificity were $99.2 \%(252 / 254)$ and $29.5 \%(43 / 146)$, respectively" should be "These results showed that the sensitivity and specificity were $99.2 \%(252 / 254)$ and $70.5 \%(103 /$ 146), respectively".

The authors apologize for this error and advise it does not affect the conclusions of the paper.

\section{Publish your work in this journal}

Risk Management and Healthcare Policy is an international, peerreviewed, open access journal focusing on all aspects of public health, policy, and preventative measures to promote good health and improve morbidity and mortality in the population. The journal welcomes submitted papers covering original research, basic science, clinical \& epidemiological studies, reviews and evaluations, guidelines, expert opinion and commentary, case reports and extended reports. The manuscript management system is completely online and includes a very quick and fair peer-review system, which is all easy to use. Visit http://www.dovepress.com/testimonials.php to read real quotes from published authors. 